\title{
The Relevance of deep ecological principles in Aquatic Crisis: A philosophical Analysis
}

\author{
Osebor Ikechukwu Monday
}

Lecturer. Department of Arts and Humanities

Delta State Polytechnic Ogwashi-Uku PmB 1030, Nigeria

Email osebormonday1@gmail.com or Osebordarry@yahoo.com

Orcid Number: https://orcid.org/0000-0002-2642-662X

DOI: https://doi.org/10.3329/bioethics.v11i2.50392

\begin{abstract}
Ethics is a branch of philosophy that analyzes right or wrong of an action. Ethics studies all aspect of human activities; which water pollution is one. Water pollution is the emission of waste or chemicals into water bodies at a quantity that is harmful to man and the aquatic organisms. The Effects of water pollution include mass extinction species, decrease in the biodiversity, and scarcity of fresh water. The question to ask is "how can water pollution be ameliorated if not totally eradicated?" Using the method of philosophical analysis, the paper suggests that the implementation of deep ecological principles by policy makers would be abatements and environmental consciousness for the common good of the society.
\end{abstract}

Keywords: Aquatic crisis, relational ethics, "I and Thou", vital needs, anthropocentricism, aquaculture, biocentric equality, self- realization and Ukama philosophy

Introduction: Aquatic crisis is one of the environmental challenges facing humanity. In the last decades, human habits have been conditioning the normal functioning of life on the planet ${ }^{1}$.

Mother earth is in great perils. Human activities and the demand for resources have created enormous pressure and stress on the sustainability of Earth. Resource depletion and environmental devastation have plagued the world in the last several decades, creating havoc to the environment and the life of species inhabiting it, which includes the human ${ }^{2}$.

Aquaculture is the rearing of aquatic animals and the cultivation of aquatic plants for food $^{3}$. Aquaculture covers the farming of both animals (including crustaceans, finfish and mollusks) and plants (including seaweeds and freshwater macrophytes $)^{4-5}$.

With the improvement of science and technology, the traditional method of fishing has changed to Aqua-mechanization. Aquamechanization is concerned with the use of Sophisticated farming techniques ${ }^{6}$. Bottom trawling is a method of fish harvesting. It is aimed at creating wealth for farmers. The implication of commercial fish harvesting, nature is conceived as a means to an end. We maintain that aqua-mechanization has played important role in the aquatic crisis. The industrial sector had produced jobs, profits, expanded the quality of life, but it equally alienated human beings from nature ${ }^{7}$. 
However, Aquaculture accounts for over $50 \%$ of the world food market for protein, fish products and it provides income for farmers but alienated man from the environment.

Environmental problems have developed chiefly because of man's rapaciousness. The belief that natural resources are inexhaustible characterized the early development of this nation, a period replete with examples of extravagant waste of forests, land, minerals, water, and wildlife. Human behavior in this decade contributes litter, pollution, improper use and depletion of resources, and a continuing destruction of natural balances and cycles essential to life ${ }^{8}$.

A reflection the negative relationship between human and nature, there is need for an ontological shift, from the anthropocentric perception of nature to what nature is; the (essence) ${ }^{9}$. The ontological shift would lead humankind to reconsider environmental and agricultural ethics. In light of the aquatic crisis, strong anthropological views of nature would give birth to ethical thinking and judicious use of environment and its resources.

Cyanide fish harvesting is a negative attitude of the aquatic farmers ${ }^{9}$. This approach is typically used in the aquariums. It involves the application of sodium cyanide into a fish habitat. The cyanide-fishing technique does not just kill the desired fish. It kills other aquatic organisms such as coral reefs. Apart from the killing of the non-desired organisms, cyanide-fishing harvesting pollutes the non-targeted habitat, which causes the aquatic crisis. Dayanthi Nugegoda and Golam Kibria argue that

Disruption of fish thyroid function by environmental stressors has the potential to result in deleterious effects including the inhibition of sperm production, reduction in egg production, gonad development, ovarian growth, swimming activity, fertilization and increase in larval mortality ${ }^{10}$.

The aquatic stressors could lead to the extinction of humanity. A critical question is, how can an intelligent species such as human, seek to harvest a few species of fish, using a method that contaminated the entire environment? We contend that human hurtful relationship with the environment forwarded a pessimistic view and a blind symbiotic history of interactions. This is alarming! It is a distortion of the food chain. The unsystematic application of chemicals, pesticides, wild fish harvesting, and the use of explosives in a habitat affects the access to fresh water and its resources.

Human assaults upon the environment would lead to a possible destruction of the biotic and abiotic communities ${ }^{11}$. Now, the human race is challenged than before, to exhibit our mastery, not over nature but ourselves.

The fight to preserve the environment must continue and this is the focus of the deep ecological principles. Carson did not oppose the use of chemicals for the exploration of nature, but the acceptable methods should be used to avoid the environmental crisis: "I contend that we have put poisonous and biologically potent chemicals indiscriminately into the hands of persons largely or wholly ignorant of their potentials for harm ${ }^{11}$. We have allowed these chemicals used, with little or no advance investigation of their effects on the soil, water, wildlife, and the man himself, future generations are not possible to condone our lack of prudent concern for the integrity of the natural world that supports all life"11. We maintain that environment education that focuses on deep 
ecological principles would be a panacea to the aquatic crisis.

Anthropocentrism: Anthropocentrism is an idea that most environmental philosophy is opposed. Etymologically, anthropocentrism is a derivative of two Greek word" $\alpha \nu \theta \rho \omega \pi \mathrm{s}$ (Anthropos, or human being) and $\kappa^{\prime} \varepsilon v \tau \rho o v$ (kentron, or centre $)^{2}$. Anthropocentrism is the human-centred philosophy in the hierarchy of beings ${ }^{2}$.

The Biblical assertion; the earth is there for humans to gain dominion over. Genesis (126) God said, "Let us make man in our image, after our likeness. And let them have dominion over the fish of the sea and over the birds of the heavens and over the livestock and over all the earth and over every creeping thing that creeps on the earth" 12 . This view of course, would be the foundation of strong anthropocentrism. Ikeke cites Van Tassel that humans are much higher and above nonhumans species $^{13}$. Humankind exercises dominion over nature, and nature is there to serve human needs ${ }^{14}$. We maintain that environmental ethics shares a dislike to human- centered philosophy

Lynn White further asserts that Christianity is the most anthropocentric religion the world had seen. Christianity is absolute contrast to ancient paganism. It establishes dualism between man and nature. For Christianity, God's will, for man to exploit nature for his proper ends ${ }^{14}$. Lynn White holds that

The Christian dogma of creation, which is found in the first clause of all the Creeds, has another meaning for our comprehension of today's ecologic crisis. By revelation, God had given man the Bible, the Book of Scripture. But since God had made nature, nature also must reveal the divine mentality ${ }^{14}$.
The dualistic mindset is a hindrance to the flourishing of organisms in an environment. The danger of the dualistic mindset is that it separates human beings from the earth ${ }^{13}$. In our opinion, the notion of dominion over non-humans is an ecological misrepresentation. How can man take dominion over creation and rule over them? This assertion is could be misrepresented because the aquatic crisis is not solely explicating the teachings of dominion over nature. There are some Christian teachings such as the mystical and sacramental universe. The mystical and sacramental universe affirms that all beings have an intrinsic value, and they are participating in divine beauty; each being is a "Cosmic Christ." Today many Christian bodies are unable to apply this teaching for environmental protection and preservation ${ }^{13}$.

Is Deep Ecological Principles a Panacea to the aquatic crisis? In April 1984, George Sessions and Arne Næss developed the principles of deep ecology ${ }^{15}$. Deep ecological principles entail that humans recognizes the intrinsic worth of all life forms, and the right of non-humans to flourish in an environment. Deep ecological principles are moral obligation for humankind, to preserve and care for the nonhuman world. In addition, deep ecological principles are rooted in naturalistic ethics, concerned with respect and duties of humankind towards others. Deep ecological principles are normative ethics aimed at cleaning up the aquatic crisis for sustainable development.

The peace and survival of humanity, is halt, by the degradation of the environment. The 
security of life and property, cannot be achieved by mounting weapons (the popular concept of "defense" in a narrow sense), but through the recognition of the positive aquatic relativity. Humankind should provide the basic conditions for solving non-military problems, which threatens humanity The survival of humanity does not only depend on the military balance, but global environmental cooperation for sustainable environment. The teaching and implementation of deep ecological principles, such as the richness and diversity of all life forms, environmental self realization, biocentric equality, environmental relatedness (Ukama philosophy), and the exploration of nature only for vital needs would boast the learning of environment ethics to saving humanity from ecological disaster.

There are many deep ecological principles; in this paper will we discuss selected ecological principles that would be relevant to this study.

Self-Realization: The philosophical aphorism man 'knows thyself' is attributed to Socrates. The concept of 'man knows thyself implies self-development, selfunderstanding, self-examination, selfinterpretation $^{16}$. The inner message of the 'Self acknowledgement, is the realization of the self, as a part of a whole. I am because of nature, is the likelihood that human existence is impossible without a symbiotic relationship with others. Self- realization is not self-sufficiency, but the preservation of others for posterity sake ${ }^{16}$. Self-realization is not the 'ego' of wide fish harvesting, but a diminishing ego, and a gradual reduction in the hedonistic attitude of humans towards nature $^{17}$. The Self-realization is not selfcenteredness, but inextricably linked to, as well as the individual dissolved into the greater Self.

Self-realization is a metaphysical condition, which nobody can ever reach because of its ontological nature. Nevertheless, it is the richness and diversity of life forms, which is value and values in themselves ${ }^{15}$. Luca maintain that self-realization is the identification of the ecological self and the asymmetrical relationship between human beings and nature. The ecological selfexpounds the ontological processes of human relationship with the $\operatorname{cosmos}^{17}$. The ecological self would help to reshapes the environmental ethics, starting with environmental ontology, and the recalling of the primacy of human relationship with nature. From an ecological standpoint, selfrealization is the complexity and symbiotic conditions for the maximizing of ecological diversity $^{15}$. The above assertions are ringing affirmations that no ontological divides between humans and nature ${ }^{7}$. There is ultimately only one substance; reality is a unity, which we may call God or Nature, we are aware that we are united to the whole, alienation drops when we identify that we are parts of a whole ${ }^{18}$.

Biocentric Equality: 'Biocentric equality is one among the principles of deep ecology. It affirms that all beings have equal intrinsic value. There is no ontological part separating human beings and nature ${ }^{15}$. Here, human beings have no greater worth, than any other creature. Human being has no rights more than plants or animals. Richness and diversity 
of life forms contribute to the realization of these values in themselves ${ }^{15}$. This is an affirmation of species egalitarianism.

Species egalitarianism is characterized by the inherent worth of beings, regardless of their instrumental and utility. Humans have no reason to assume that species do not have equal moral standing, all species command equal respect. We argue that respect for nature is not negotiable because we are parts of a whole. George Sessions et al mentioned that the flourishing of human life and cultures is compatible with a substantial decrease in the human population ${ }^{15}$. The flourishing of nonhuman life requires such a decrease. We maintain that human and nature should flourish without moral superiority.

The 'Vital Need': The concept of vigorous need entails that humans have no right to reduce the richness and diversity of nature, except for the satisfaction of the vital needs. "Vital need;" is an ecological principle, which is broad and dense, owing to its vague nature. Frances Stewart refer vital need as basic needs, thus

A basic needs (BN) approach to development is one, which gives priority to meeting the basic needs of all the people. The actual content of $\mathrm{BN}$ have been variously defined: they always include the fulfillment of certain standards of nutrition, (food and water), and the universal provision of health and education services. They sometimes also cover other material needs, such as shelter and clothing, and non-material needs such as employment, participation and political liberty ${ }^{19}$.

The term "vital need" is deliberately vague to allow considerable latitude of judgments 15. The "vital need" is nature inherent in value. The intrinsic worth of all life forms can only be reducible for imperative need. The vital need implies two strands of anthropocentrism-the weak and strong anthropocentrism. Weak anthropocentrism is the view that human beings should explore nature only for vital needs. While Strong anthropocentrism, on the other hand, believes that human beings explore nature as a means to an end ${ }^{2}$ A vital need is open to rational interpretations. To some schools of thought, vital need is an imperative need, which is the opposite of "other" needs ${ }^{15}$. We argue that the meaning ofvital need requires a moral interpretation to determine the difference between vital need and other needs.

Concept of Ukama: From the African perspective, Ukama is a traditional value. It is a Shona word among the people of Zimbabwe. Ukama is a philosophy that has strong biocentrism. It is a philosophy, which deconstructs the anthropocentric perception of nature. Ukama is concerned about the well-being of the environment, kinship/relatedness and the immortality of soul $^{20}$.

Ukama is an environmental ethics. It teaches moral relationship among organisms ${ }^{21}$. Ukama is a inter-relational ethics that encourage co-existence of humanity in the bio-network. The existence of humans is dependent on the established positive relationship with others. Otherwise, humankind could face extinction ${ }^{21}$. "What has become the most frightening reality about our human existence is that the world that is extremely interconnected and the pursuit of self-interest have resulted in a rampant pollution of the environment" 20 .

Ukama rejects the superiority of humans in the hierarchy of beings. It calls for cross- 
fertilization in the relationship between organisms. The philosophy of crossfertilization, affirms that there is no separation between thou and "I and thou." This affirms that there is no ontological understanding that human beings not separated with others ${ }^{21}$.

Conclusion: In light of the above, we could answer the question "how would the aquatic crisis be ameliorated if not eradicated? This review suggested that the teaching and implementation of the deep ecological principles would help humankind to frame a positive ecological attitude in the exploration of nature for posterity sake. We suggest that deep ecological principle be integrated into school curriculum, so that citizens can be taught environmental consciousness for the common good of the society.

\section{References}

1. Ainara S, Naiara R,Jon A, Loli E, Josune A. European Journal of Sustainable Development (2020), 9, 4, 22-32. Doi:10.14207/ejsd.2020.v9n4p22.

2. Ravichandran M, and Gabriel T A. Environmental Ethics through Value-Based Education. Bangladesh Journal of Bioethics 2020; 11 (2): 19. https://doi.org/10.3329/bioethics.v11i2.49257.

3. Akinbi, J. (2012): The Niger Delta Environmental Crisis in Nigeria Journal of International Multidisciplinary, 5(63): 150-164

4. Aquaculture (N-d). http://www.fao.org/3/x6941e/x6941e04.htm ([14 August 2019])

5. Stephen, M.(2016) Gardiner and Allen, T. "Introducing Contemporary Environmental Ethics" The Oxford Handbook of Environmental Ethics, moral philosophy, Social and Political Philosophy, (2016), p. 1.

6. Sustainability For All Destructive Vs Sustainable Fishing (n-d) available from https://www.activesustainability.com/environme nt/destructive-vs-sustainable-fishing (14 August 2019).

7. Luca, V.(2018) Ecological Self and SelfRealization: Understanding Asymmetrical Relationships Through Arne Næss's Ecosophy. Journal of Agricultural and Environmental Ethics, 5( 1), p.1-8). Available from https://doi.org/10.1007/s10806-018-9715-x ([14 August 2019]).

8. Environmental crisis.(N-d): "Journal of Educational Leadership" Available from http://www.ascd.org/ASCD/pdf/journals/ed lead /el_197012_romine.pdf(14 August 2019)

9. Olawande, F. (1998): Harmful Fishing Practices in the Coastal Belt of Nigeria: Use of NonSelective Fishing Gears" Available at http://www.fao.org/3/a-an681e.Pdc $\quad(14$ Sept 2020)

10. Dayanthi N. and Golam K. (2016): "Effects of Environmental chemicals on Fish Thyroid Function: Implications for Fisheries and Aquaculture in Australia." General and Comparative Endocrinology, p. 244. Available from 10.1016/j.ygcen.2016.02.021.

11. Carson, R. (1962): Silent Spring: with an Introduction by Vice President Al Gore. (New York: Houghton Mifflin. Available from https://www.amazon.com/Silent-SpringIntroduction-Vice-President/dp/B00600Z708(14 August 2018).

12. The Holy Bible. Genesis, 1-26. Available from https://www.bibleref.com/Genesis/1/Genesis-126.html (14 August 2018).

13. Ikeke, M. (2015): The Ecological Crisis and The Principle Of Relationality In African Philosophy. Philosophy Study, 5(2): 179-186. Available from http://www.doi:

$10.17265 / 2159-$ $5313 / 2015.04 .001$

14. Lynn, W. "The Historical Roots of Our Ecological Crisis". Science, (1967), p. 155: 12031207. Available at http://www.cmu.ca/faculty/gmatties/lynnwhitero otsofcrisis.pdf (14 August 2019).

15. Naess, A. and Sessions, G. "Basic Principles of Deep Ecology" (1984). Available at https://www.deepecology.org ([14 August 20219). 
16. Talukder, H. (2016) For "Self-Realization." The Ultimate Norm of Arne Naess's Ecosophy .T. Symposium. p.219-235. Available from https://philarchive.org/archive/TALOS.frican.

17. Zimmerman, M. (1998): Deep Ecology, Ecoactivism and Human Evolution. Available from https://ogigaya.wordpress.com/think-sangha/tsj3html/zimmerman-htm.(14 August 2019).

18. David, S. (1998): "Are All Species Equal"? Journal of Applied Philosophy. Available from http://rintintin.colorado.edu/ vancecd/phil3140/ Schmidtz.pdf.( 14 August 2019).

19. Frances S. (1985): A Basic Needs Approach to Development. In: Planning to Meet Basic Needs.

Author Contribution: The Manuscript is an Unpublished PhD Seminar Paper, written by Osebor Ikechukwu Monday, supervised by prof. Ikechukwu Ogugua. Department of Philosophy, Nnamdi Azikiwe University Awka, Anambra State Nigeria.
Palgrave Macmillan London P.1-13. Available from https://doi.org/10.1007/978-1-349-17731$\underline{8} 1$.

20. Murove, M. "An African Commitment to Ecological Conservation through the Concept Of Ukama And Ubuntu. Mankind." Quarterly, (2004), p. 40.

21. Osebor, I. (2012): African Concept of Ukama: Appraisal (Unpublished B.A Project, Department of Philosophy and Religious Studies Delta State University Nigeria, Abraka. pp.38-49.

Conflict of Interest: No Conflict of interest. 